\title{
ABSTRACT \\ THE EFFECTS OF A MEDICINE BALL TRAINING PROGRAM ON RUNNING ECONOMY
}

by Veronica Michelle Rasicci

The purpose of this study was to determine the effects of a medicine ball training program on running economy (RE). RE has been shown to improve with the addition of concurrent explosive strength training, plyometrics, and heavy load resistance training. However, there is little research on the effects of functional resistance training on RE. Seventeen trained endurance runners $\left(\mathrm{VO}_{2} \max =54.5 \pm 10.0 \mathrm{~mL} / \mathrm{kg} / \mathrm{min}\right)$ underwent baseline testing to determine anthropometric, upper body and core muscular endurance tests, RE at two different speeds, and $\mathrm{VO}_{2}$ max. Participants were matched for gender and $\mathrm{VO}_{2} \mathrm{max}$ and randomly assigned to either the 6-week medicine ball (MB; $n=9(4 \mathrm{M})$ ) training group or control $(\mathrm{CON} ; \mathrm{n}=8(3 \mathrm{M})$ ) group. Tests were repeated after the 6-week MB training program. Statistical analys is was performed using a one-way ANOVA. In all cases, statistical significance was set at $p \leq 0.05$. Results of the one-way ANOVA showed a significant change in curl ups $(p=0.03)$ in the MB group. No significant differences were observed for change in push-ups nor running economy at either speed. Therefore, concluding that a concurrent medicine ball training program improved core musculature endurance without affecting running economy. 


\author{
A Thesis \\ Submitted to the \\ Faculty of Miami University \\ in partial fulfillment of \\ the requirements for the degree of \\ Master of Science \\ by \\ Veronica Michelle Rasicci \\ Miami University \\ Oxford, Ohio \\ 2017 \\ Advisor: Kyle Timmerman, $\mathrm{PhD}$ \\ Reader: Julie M. Cousins, $\mathrm{PhD}$ \\ Reader: Kevin D. Ballard, PhD
}

C2017 Veronica Michelle Rasicci 
This Thesis Titled

\section{THE EFFECTS OF A MEDICINE BALL TRAINING PROGRAM ON RUNNING ECONOMY}

by

Veronica Michelle Rasicci

has been approved for publication by

College of Education, Health, and Society

and

Department of Kinesiology and Health

Dr. Kyle Timmerman

Dr. Julie M. Cousins

Dr. Kevin D. Ballard 


\section{Table of Contents}

Chapter One: Introduction $\quad 1$

Chapter Two: Method 3

Participants 3

Procedures 3

Height, Weight, and Body Composition 3

$\begin{array}{ll}\text { Muscular Endurance } & 4\end{array}$

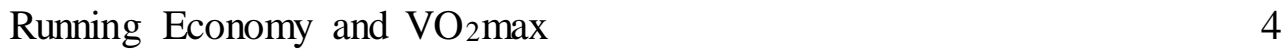

Training 5

Statistical Analysis $\quad 5$

Chapter Three: Results 6

Chapter Four: Discussion $\quad 8$

$\begin{array}{ll}\text { Strengths and Limitations } & 10\end{array}$

$\begin{array}{ll}\text { Practical Application } & 10\end{array}$

$\begin{array}{ll}\text { Conclusion } & 11\end{array}$

$\begin{array}{ll}\text { References } & 12\end{array}$

$\begin{array}{ll}\text { Appendix A: Medicine Ball Training Program Outline } & 14\end{array}$ 


\section{List of Tables}

Table 1: Descriptive Characteristics $\quad 6$

Table 2: Performance Variables $\quad 7$ 


\section{CHAPTER ONE \\ INTRODUCTION}

Athletes are continually in search of ways to improve their performance. Success in distance running depends on multiple factors including $\mathrm{VO}_{2} \max$, lactate threshold, and running economy (RE). RE is defined as "the energy demand for a given velocity of submaximal running" and can be measured by steady-state oxygen consumption $\left(\mathrm{VO}_{2}\right)$ at any given running speed (13). $\mathrm{RE}$ is important because runners with good RE use less oxygen to run at a set speed compared to those runners with a lower RE. Thus, training strategies that increase RE are likely to translate to improvements in running performance $(4,6,7,13,14)$.

A variety of studies have examined the possible factors that may have an influence on RE and running performance $(4,6,7,9,10,13-17)$. One factor that has been shown to influence $\mathrm{RE}$ is neuromuscular characteristics $(4,16)$. Many studies have found improvements in RE with the addition of a variety of resistance training (RT) programs $(4,6,7,9,14,15,17)$. One study (6) focused on the addition of a full body traditional RT program, performed 3 days per week for 10 weeks, while continuing with their current endurance-training program. The addition of the full body traditional RT program resulted in a significant improvement in RE by $4 \%$ (6). A second study (17) focused on a lower body traditional RT program. They found a 5\% improvement in $\mathrm{RE}$ when these lower body exercises were performed $3 \mathrm{~d} / \mathrm{wk}$ for 8 wks (17). Explosive RT has also been shown to improve RE by $8.1 \%$ when training was performed $3 \mathrm{~d} / \mathrm{wk}$ for 9 wks (9). It has been suggested that the improvements shown in RE after the addition of a RT program may be due to an increase in leg strength and the ability to change motor unit recruitment patterns, which allows the body to function more efficiently while running (6).

Functional RT is defined as weighted practical movements that mimic everyday activities. When comparing traditional RT to functional RT, both have been found to improve muscular strength and endurance (8). Additionally, evidence suggests that functional RT improves muscular strength and endurance greater than traditional RT, when training at the same intensity (8). This finding suggests that functional RT, in addition to traditional RT, may improve overall muscular strength and endurance. There is also evidence to suggest that improvements from a functional RT program lasted longer than improvements from a traditional RT program, after a period of detraining (2). As previously mentioned, there has been a fair amount of research on functional 
RT, but little research in terms of functional RT's effects on different factors on performance, specifically RE.

Exercises that utilize a medicine ball is an example of functional RT. In a study that followed a functional medicine ball training program (3), significant improvements were made in speed, agility, lower body and upper body power, as well as abdominal and upper body strength. Alternatively, one study focused on the use of a six-week Swiss ball RT program and its effects on core stability and RE (16). The addition of a Swiss ball program significantly enhanced core stability but did not result in an improvement in RE (16). Runners have been gaining interest in functional RT due to its ability to be performed anywhere, that it does not require a great deal of space, time, or equipment, and because of the similar improvements found in muscular strength and endurance produced by functional and traditional RT (8).

However, there is a lack of research examining the effect of functional RT on RE. Additionally, the appeal of functional RT is beginning to increase. This increase in the appeal of functional RT may be due to functional RT's feasibility. Thus, the primary purpose of the present study is to determine if a six-week medicine ball training program improves $\mathrm{RE}$ in trained endurance runners. We hypothesized that a six-week medicine ball training program will improve RE and core and upper body muscular endurance in trained endurance runners, compared to a control group of similarly trained runners. 


\section{CHAPTER TWO}

\section{METHOD}

\section{Participants}

Seventeen male and female trained $\left(\mathrm{VO}_{2} \max =54.5 \pm 10.0 \mathrm{~mL} / \mathrm{kg} / \mathrm{min}\right)$ endurance runners volunteered to participate in this study. Participants completed a health history questionnaire and a running experience questionnaire. The Institutional Review Board at Miami University approved the study protocol and written informed consent was obtained from all study participants. Nine participants were randomly assigned to a medicine ball training group (MB) while eight participants were randomly assigned to a no RT control group (CON). Random assignment of participants was done through a random number generator. All participants were running a minimum of 15 miles per week, averaging 25 miles per week, and had not participated in a RT program, for the 12 weeks leading up to the study. The participants averaged 10.2 years of running experience.

\section{Procedure}

The participants were matched for gender and baseline $\mathrm{VO}_{2} \mathrm{max}$, and then randomized into either $\mathrm{CON}$ or $\mathrm{MB}$. Both $\mathrm{CON}$ and $\mathrm{MB}$ completed the pretest, and were asked to maintain their normal running training. The day prior to the pretest, subjects were asked to refrain from any strenuous activity. The pretest lasted approximately one hour and consisted of height and weight measurements, body composition analysis, the American College of Sports Medicine (ACSM) push-up test, the ACSM curl up test, a RE test, and a maximal oxygen consumption $\left(\mathrm{VO}_{2} \max \right)$ test (11). The week immediately following the pretesting, MB performed six weeks of supervised medicine ball RT, meeting with research assistants on three nonconsecutive days per week. CON refrained from starting a RT program immediately after receiving their group assignment. Both groups were instructed to continue with their normal running program. The week directly after the six-week period, both groups completed the post-tests. The post-tests consisted of weight measurement, body composition analysis, the ACSM push-up and curl up tests, and a RE test.

Height, Weight, and Body Composition 
Height was measured using a Seca stadiometer to the nearest one-half centimeter. Weight and body composition were measured using a bioelectrical impedance analyzer (BIA, InBody 770, Biospace Co., LTD., Cerritos, CA.). Height, weight, and body composition were measured without socks or shoes, while wearing shorts and a t-shirt. Body mass index (BMI) was calculated from the participant's height and weight.

\section{Muscular Endurance}

The ACSM push-up and curl up tests were used to assess muscular endurance (11). The maximal number of push-ups performed consecutively without rest were counted. The test was over when the participant strained forcibly or were unable to maintain proper form for two consecutive push-ups. For the curl up test, subjects were asked to complete as many curl ups as they could until they could no longer maintain a cadence of 40 beats per minute or reached 75 curl ups. A repetition was counted every time a subject reached the bottom position.

\section{Running Economy and $\mathrm{VO}_{2} \mathrm{Max}$}

Participants warmed up at a self-selected, moderate intensity speed on a motor driven treadmill for five minutes. Once the warm up was completed, the participants began the RE test followed by the $\mathrm{VO}_{2} \max$ test.

RE was measured by completing two continuous 5-minute submaximal treadmill runs at speeds of 187.8 and $203.9 \mathrm{~m} / \mathrm{min}(7.0$ and $7.6 \mathrm{mph})$. These two speeds were selected for the RE tests based off ACSM's metabolic equations. The two speeds were estimated to have participants reach steady state oxygen consumption in under five minutes. During the 10 minute RE test, the participant's oxygen consumption was measured using the Parvo Medics metabolic cart (True One 2400, Parvo Medics, Murray, UT). The average oxygen consumption from minutes 2-5 and 6-10 were calculated and used in the analysis. The participants rested for 10 minutes after completing the RE test before beginning the graded exercise test.

The participant's $\mathrm{VO}_{2} \max$ was determined by a graded exercise test. The treadmill speed was set at the participant's self-reported $10 \mathrm{~K}$ race pace. The test started at a $0 \%$ incline, with the incline increasing $2 \%$ every two minutes until the subject reached volitional fatigue or requested to stop. The $\mathrm{VO}_{2}$ max test was determined successful if there was a plateau $(\leq 2 \mathrm{~mL} / \mathrm{kg} / \mathrm{min})$ in oxygen consumption with an increase in work rate, or two of the following three criteria; rating of 
perceived exertion $(\mathrm{RPE})>18$, respiratory exchange ratio $(\mathrm{RER}) \geq 1.1$, heart rate within \pm 10 beats per minute of estimated maximal heart rate. The Parvo Medics metabolic cart was used to measure oxygen consumption during the graded exercise test.

\section{Training}

All participants were instructed to maintain their current aerobic training throughout the study and not to begin a RT program. Regardless of assigned group, every participant kept a training $\log$ of their personal endurance training. At the midpoint of the six-week study, an email was sent $\mathrm{CON}$ subjects to ensure that they were still running regularly and had not begun a RT program. The MB participants met with researcher assistants on three non-consecutive days a week for six weeks and completed a series of 18 full-body progressive workouts with a medicine ball, following the outline presented in Appendix A. The workouts consisted of a series of medicine ball lunges, shoulder presses, sit-ups, planks, push-ups, and slams. The weight of the medicine ball was self-selected by the participants and remained consistent throughout the duration of the study, as the load of each exercise progressed over the course of the six-week program. The participants chose from either a $2.73 \mathrm{~kg}, 3.64 \mathrm{~kg}$, or $4.55 \mathrm{~kg}$ medicine ball. The RT program was made available for the control group after the completion of the post-tests.

\section{Statistical Analysis}

Statistical analyses were performed using SPSS, version 23.0 (Statistical Package for Social Science Software, Chicago, IL). All data were normally distributed and descriptive statistical analyses are presented in mean \pm standard deviation. A one-way ANOVA was used to determine if there were any significant differences between MB's and CON's change scores. In all cases, statistical significance alpha was set to $p<0.05$. 


\section{CHAPTER THREE}

\section{RESULTS}

A total of 17 trained endurance runners completed the duration of this study. Characteristics of the runners by $\mathrm{MB}$ and $\mathrm{CON}$ are presented in Table 1. Prior to the intervention, the two groups were similar in all variables measured. The MB group ran on average 17.97 miles a week, while the CON group averaged 17.43 miles a week during the six-week study $(p=0.86)$.

Table 1: Descriptive Characteristics

\begin{tabular}{|c|c|c|c|}
\hline & $\begin{array}{c}\text { Intervention (MB) } \\
(\mathrm{n}=9 ; F=5, M=4)\end{array}$ & $\begin{array}{c}\text { Control (CON) } \\
(\mathrm{n}=8 ; F=5, M=3)\end{array}$ & $p$-value \\
\hline Age (years) & $23.22 \pm 10.29$ & $27.75 \pm 12.20$ & 0.42 \\
\hline Height $(\mathrm{cm})$ & $170.33 \pm 11.36$ & $172.13 \pm 8.17$ & 0.72 \\
\hline Weight (kg) & $65.38 \pm 9.51$ & $65.60 \pm 9.59$ & 0.96 \\
\hline Body Fat (\%) & $19.20 \pm 10.49$ & $19.33 \pm 8.43$ & 0.98 \\
\hline BMI $\left(\mathrm{kg} / \mathrm{m}^{2}\right)$ & $22.47 \pm 2.34$ & $22.05 \pm 2.58$ & 0.73 \\
\hline $\begin{array}{l}\text { RE at } 187.8 \mathrm{~m} / \mathrm{min} \\
(\mathrm{mL} / \mathrm{kg} / \mathrm{min})\end{array}$ & $37.77 \pm 2.97$ & $34.54 \pm 4.19$ & 0.08 \\
\hline $\begin{array}{l}\text { RE at } 203.9 \mathrm{~m} / \mathrm{min} \\
(\mathrm{mL} / \mathrm{kg} / \mathrm{min})\end{array}$ & $41.90 \pm 3.28$ & $38.57 \pm 4.93$ & 0.12 \\
\hline $\begin{array}{l}\mathrm{VO}_{2} \mathrm{max} \\
(\mathrm{mL} / \mathrm{kg} / \mathrm{min})\end{array}$ & $54.83 \pm 9.38$ & $54.12 \pm 12.00$ & 0.89 \\
\hline
\end{tabular}

Values are means \pm SD unless otherwise noted.

The participants in the MB group attended an average of 17 out of the 18 training sessions, resulting in a 93\% adherence rate. After the six-week training program, a significant $(p=0.01)$ improvement in muscular endurance was observed by the increased number of curl ups successfully completed for the MB (Table 2). Both MB and CON group had a non-significant increase in their number of push-ups compared to their pretest results (Table 2).

As shown in Table 2, there were no significant changes in RE for either the MB or CON. 
Table 2: Performance Variables

\begin{tabular}{|l|l|l|l|l|l|c|}
\hline & \multicolumn{3}{|c|}{ Medicine Ball Intervention } & \multicolumn{3}{c|}{ Control } \\
\hline & \multicolumn{1}{|c|}{ Pre } & \multicolumn{1}{c|}{ Post } & \multicolumn{1}{c|}{$\Delta$} & \multicolumn{1}{c|}{ Pre } & \multicolumn{1}{c|}{ Post } & $\Delta$ \\
\hline Body Fat (\%) & $19.20 \pm$ & $19.59 \pm$ & $0.39 \pm$ & $19.33 \pm$ & $19.83 \pm 7.67$ & $0.51 \pm 2.37$ \\
& 10.49 & 10.48 & 1.43 & 8.43 & & \\
\hline Push-ups (\#) & $33.67 \pm$ & $42.11 \pm$ & $8.44 \pm$ & $26.63 \pm$ & $31.75 \pm 8.89$ & $5.13 \pm 6.58$ \\
& 7.12 & 8.71 & 7.37 & 8.98 & & \\
\hline Curl Ups (\#) & $46.67 \pm$ & $64.56 \pm$ & $\mathbf{1 7 . 8 9} \pm$ & $42.75 \pm$ & $44.50 \pm 20.09$ & $1.75 \pm 8.17$ \\
& 22.73 & 13.06 & $\mathbf{1 7 . 1 2}$ & 20.25 & & \\
\hline Running & $37.77 \pm$ & $37.47 \pm$ & $-0.30 \pm$ & $34.70 \pm$ & $35.10 \pm 5.09$ & $0.36 \pm 1.02$ \\
Economy at & 2.97 & 2.85 & 1.87 & 4.51 & & \\
$187.8 \mathrm{~m} / \mathrm{min}$ & & & & & & \\
(mL/kg/min) & & & & & & \\
\hline Running & $41.90 \pm$ & $41.92 \pm$ & $0.02 \pm$ & $38.13 \pm$ & $39.29 \pm 5.17$ & $0.72 \pm 1.25$ \\
Economy at & 3.28 & 3.11 & 2.11 & 5.10 & & \\
203.9 m/min & & & & & & \\
(mL/kg/min) & & & & & & \\
\hline
\end{tabular}

Values are means $\pm S D$ unless otherwise noted.

Bold type represents significantly different improvements from baseline results $(p \leq 0.05)$ 


\section{CHAPTER FOUR}

\section{DISCUSSION}

This study investigated the effects of a six-week medicine ball training program on RE and muscular endurance of the upper body and core. The participants for this study were trained male and female runners. Upon investigation, it was found that the addition of a medicine ball training program resulted in significant increases in core muscular endurance, as assessed by ACSM's curl up test. A non-significant improvement in upper body muscular endurance was also found, while no change in RE was witnessed. The absence of change in RE is evident at both 187.8 $\mathrm{m} / \mathrm{min}$ and $203.9 \mathrm{~m} / \mathrm{min}$.

Several studies have found an improvement in RE following the addition of explosive strength training program in both trained and highly trained runners $(4,9,14,15,18)$. These improvements in RE may be due to the adaptations of plyometric training, such as increased motor unit activation, the enhanced ability to generate power via the stretch-shortening cycle, and the increased stiffness of the muscle-tendon system, which allows the body to store more elastic energy (13). These adaptations allow for more force generation from the muscles without proportionate increases in the metabolic energy requirement (13). A six-week concurrent plyometric training study (18) found 2-3\% improvements in RE in trained (VO2max $=52.2 \pm 8.1$ $\mathrm{mL} / \mathrm{kg} / \mathrm{min})$ runners. Furthermore, an alternative study (15) that also used trained $\left(\mathrm{VO}_{2} \max =\right.$ $57.7 \pm 6.6$ ) runners, found significant improvements in RE at three different submaximal speeds, following the addition of a six-week plyometric training program. Conversely, we found no significant changes in RE following a six-week functional medicine ball training program. The improvement in $\mathrm{RE}$ found in the previous two studies may be due to the higher intensity nature of plyometric training, which included explosive jumps and bounds, compared to the current study's training program.

A study that looked at the effects of a nine-week explosive-strength training program on RE, that used highly trained runners $(68.0 \pm 3.0 \mathrm{~mL} / \mathrm{kg} / \mathrm{min})$, revealed a significant improvement $(8.1 \%)$ in RE (9). Similarly, in a separate study (14) that also explored the effects of nine weeks of plyometric training on RE, found a $4.1 \%$ improvement, in highly trained $(71.1 \pm 6.0 \mathrm{~mL} / \mathrm{kg} / \mathrm{min})$ endurance runners. The difference in our study's findings and the findings of the previous two studies may be due to the differences in the intervention, as well as subject differences. The previous two studies both used plyometric and explosive training with highly trained runners, 
where the current study was comparably more moderate in intensity and used trained runners (9, 14).

The addition of a traditional strength training programs has typically shown improvements in RE $(4,6,17)$. In a study that explored heavy traditional strength training, it was shown to significantly improved $\mathrm{RE}$ by $6.2 \%$ after four weeks of training (4) in well-trained $\left(\mathrm{VO}_{2} \mathrm{max}\right.$ of $61.8 \pm 5.1 \mathrm{~mL} / \mathrm{kg} / \mathrm{min}$ ) runners. The same study also found that the addition of an explosive strength training program did not significantly improve RE (4). This finding suggests that in short-duration studies, heavy traditional strength training may be more effective at improving RE than explosive strength training.

Other studies have demonstrated improvements in RE with the addition of traditional strength training $(6,17)$. One eight-week study, conducted with trained $\left(\mathrm{VO}_{2} \max\right.$ of $59.0 \pm 4.4$ $\mathrm{mL} / \mathrm{kg} / \mathrm{min}$ ) runners, found that the supplementation of maximal strength training, i.e. lifting at a high percentage (approximately 90\%) of the participant's individual one repetition max (1RM), improved RE by $5 \%$ (17). Similarly, a $4 \%$ improvement in RE was discovered in a study that focused on trained female runners $\left(\mathrm{VO}_{2} \max =51.0 \pm 2.3 \mathrm{~mL} / \mathrm{kg} / \mathrm{min}\right)$, and a 10 -week training program (6). The findings of these two studies suggest that RE may be improved through the addition of a training program that focuses on traditional RT. The two previously mentioned studies lasted eight and 10 weeks, while the current study lasted six weeks. These discrepancies may be due to differences in the duration of the interventions, as well as the training interventions themselves $(6,17)$. Overall, the addition of traditional strength training as shown to enhance RE, which may be a result of improved mechanical efficiency, muscle coordination, and motor recruitment patterns (7).

Consistent with previous functional strength training studies, our results suggest that a medicine ball training program is associated with increased core strength and endurance $(3,16)$. The improvement in core endurance is demonstrated by the significant increase in the number of curl ups completed by MB compared to CON. A six-week Swiss ball training regime (16) found significant improvements in core strength with no significant differences in RE, in trained $\left(\mathrm{VO}_{2} \max\right.$ of $55.3 \pm 5.7 \mathrm{~mL} / \mathrm{kg} / \mathrm{min}$ ) runners. Additionally, a separate study that used high school physical education students (3) found significant increases in core strength and endurance when using a six-week medicine ball training program. Core strength is important to runners as a strong core is the foundation to maximizing the power that is produced from the legs, and for 
maintaining proper running form without over-excessive head and arm swing (1). Additionally, a strong core helps runners maintain proper posture and proper running technique, which has shown to have an influence on $\operatorname{RE}(10,13,16)$.

While not significant, this study resulted in an increase in upper body endurance in both MB and CON groups. Across both groups, there was an increase in the total number of push-ups. A study that utilized a 12-week medicine ball training program for female handball players (5) found a significant increase in upper body strength. The current study's non-significant increase in upper body endurance may be due to the length of the study compared to the length of the formerly mentioned study (5). The duration of this current study was chosen because previous studies have shown improvements in RE with six weeks or less of training $(4,15,18)$. Additionally, the duration of this study was chosen because neurological adaptations begin to take effect at the beginning of any RT program, and neurological adaptations have been shown to influence RE (4, 12, 16). Although prior studies have shown an increase in muscular endurance and simultaneous improvements in RE after six weeks or less of concurrent RT, more research is needed as to why our study did not produce similar effects in regards to $\mathrm{RE}(4,15)$.

\section{Strengths and Limitations}

One strength of this study was the adherence to the training program, with $93 \%$ of all sessions being attended. Another strength of this study was exploring the use of a functional medicine ball training program, which hasn't been the focus of previous studies, in regards to RE. Thirdly, this study used randomized subjects in both groups. After an extensive search of the literature, this is one of the few studies that focused on trained participants, not untrained or highly trained runners, which adds to the growing research on RE. Focusing on a trained group of endurance runners allows the findings of this study to be applicable to a larger group of endurance runners. One limitation of this study is its small sample size, which limits the power of this study. A retrospective power calculation revealed a power value of 0.788 . Also, the application of this study's findings is limited to the trained running population whom are which are not currently participating in a RT program.

\section{Practical Application}

A medicine ball training program is one example of a functional RT program. Medicine balls are the ideal pieces of equipment because they are low in cost, easily transportable, do not require special training to use, and can be used virtually anywhere. The results of this study suggest that 
a concurrent medicine ball training program and a running program, in trained endurance runners, produced a significant increase in core endurance. This increase in core endurance is evident without enhancing RE, in untrained (resistance trained) runners. This increase in core endurance would be beneficial for runners because it may help with improving running form, and therefore, running performance $(10,13,16)$. Although improvements of muscular endurance are expected with this type of program, more research is needed as to why our study did not find significant improvements in upper body muscular endurance. This further research is warranted to provide insight for runners on how to train efficiently and effectively, in order to maximizing their running performance.

\section{Conclusion}

A six-week medicine ball training program significantly increased core endurance. Additionally, the medicine ball training program did not lead to an improvement in RE. Further research is needed to continue the investigation into supplemental functional RT and its possible effects on RE. 


\section{LIST OF REFERENCES}

1. Barnes, D. (2002) What type of strength training do distance runner do or need? Modern Athlete Coach, 40, 27-37.

2. de Vreede, P. L., Samson, M. M., van Metteren, N. L.U., Duursma, S. A., \& Verhaar, H. J.J. (2005). Functional-task exercise versus resistance strength exercise to improve daily function in older women: A randomized, controlled trial. Journal of American Geriatrics Society, 53(1), 2-10.

3. Faigenbaum, A. D. \& Mediate, P. (2006). Effects of medicine ball training on fitness performance of high-school physical education students. The Physical Educator, 63(3), 160-167.

4. Guglielmo, L.G. A., Greco, C. C., \& Denadai, B. S. (2009). Effects of strength training on running economy. International Journal of Sports Medicine, 30, 27-32.

5. Ignjatovic, A. M., Markovic, Z. M., \& Radovanovic, D. S. (2012). Effects of 12-week medicine ball training on muscle strength and power in young female handball players. Journal of Strength and Conditioning Research, 26(8), 2166-2173.

6. Johnston, R.E, Quinn, T.J, Kertzer, R., \& Vroman, N.B. (1997). Strength training in female distance runners: Impact on running economy. Journal of Strength and Conditioning Research, 11(4), 224-229.

7. Jung, A. P (2003). The impact of resistance training on distance running performance. Sports Medicine, 33(7), 539 - 552.

8. Lohne-Seiler, H., Torstveit, M. K., \& Anderssen, S. A. (2013). Traditional versus functional strength training: Effects on muscle strength and power in the elderly. Journal of Aging and Physical Activity, 21, 51-70.

9. Paavolainen, L., Hakkinen, K., Hamalainen, I., Nummela, A., \& Rusko, H. (1999). Explosive-strength training improves $5-\mathrm{km}$ running time by improving running economy and muscle power. American Physiological Society, 1527-1533.

10. Peikriszwili Tartaruga, M., Brisswalter, J., Peyré-Tartaruga, L. A., Vargas Ávila, A. O., Lima Alberton, C., Coertjens, M., Lusa Cadore, E., Leandro Tiggemann, C., Marczwski Silva, E. \& Martins Kruel, L. F. (2012) The relationship between running economy and biomechanical variables in distance runners. Research Quarterly for Exercise and Sport, 
83(3), 367-375.

11. Pocatello, L. S., Arena, R., Riebe, D., \& Thompson, P. D. (Eds.). (2014). ACSM's guidelines for exercise testing and prescription (9th ed.). Baltimore, MD: Lippincott Williams \& Wilkins.

12. Powers, S. K., \& Howley, E. T. (2012). Exercise physiology: Theory and application to fitness and performance (8th ed.). New York, NY: McGraw Hill.

13. Saunders, P.U., Pyne, D.B., Telford, R.D., \& Hawley, J.A. (2004). Factors affecting running economy in trained distance runners. Journal of Sports Medicine, 34(7), 465485.

14. Saunders, P. U., Telford, R. D., Pyne, D. B., Peltola, E. M., Cunningham, R. B., Gore, C. J., \& Hawley, J. A. (2006). Short-term plyometric training improves running economy in highly trained middle and long distance runners. Journal of Strength and Conditioning Research, 20(4), 947-954.

15. Spurrs, R. W., Murphy, A. J., \& Watsford, M. L. (2003). The effect of plyometric training on distance running performance. European Journal of Applied Physiology, 89, $1-7$.

16. Stanton, R., Reaburn, P. R., \& Humphries, B. (2004). The effect of short-term Swiss ball training on core stability and running economy. Journal of Strength and Conditioning Research, 18(3), 522-528.

17. Storen, O., Helgerud, J., Stoa, E. M., \& Hoff, J. (2008). Maximal strength training improves running economy in distance runners. Medicine \& Science in Sports \& Exercise, 1089-1094.

18. Turner, A. M., Owings, M., \& Schwane, J. A. (2003). Improvement in running economy after 6 weeks of plyometric training. Journal of Strength and Conditioning Research, $17(1), 60-67$. 


\section{Appendix A:}

Medicine Ball Training Protocol: Weeks 1 \& 2:

\begin{tabular}{|c|c|c|}
\hline Weekly Session 1 & Weekly Session 2 & Weekly Session 3 \\
\hline $\begin{array}{l}\text { Around the World }-1 \times 8 \\
\text { (each way) }\end{array}$ & $\begin{array}{c}\text { Haybales }-1 \text { x } 10 \text { (each } \\
\text { way) }\end{array}$ & Haybales -1 x 8 (each way) \\
\hline Haybales -1 x 8 (each way) & $\begin{array}{c}\text { Seated twist w/ Med Ball - } \\
1 \times 20 \mathrm{sec}\end{array}$ & Woodchops -1 x 8 \\
\hline Woodchops $-1 \times 8$ & Med Ball Plank -1 x $45 \mathrm{sec}$ & $\begin{array}{c}\text { Bent Arm Rotations }-1 \times 8 \\
\text { (each way) }\end{array}$ \\
\hline $\begin{array}{c}\text { Straight Arm Rotations }-1 \\
\text { x } 8\end{array}$ & $\begin{array}{l}\text { V-ups with } \\
6\end{array}$ & $\begin{array}{c}\text { Straight Leg Med Ball Sit- } \\
\text { up }-1 \times 20\end{array}$ \\
\hline Haybales -1 x 8 (each way) & $\begin{array}{c}\text { Russian Hamstring }-1 \times 20 \\
\text { (each leg) }\end{array}$ & Med Ball Plank - 1 x $45 \mathrm{sec}$ \\
\hline $\begin{array}{c}\text { Bent Arm Rotations }-1 \times 8 \\
\text { (each way) }\end{array}$ & $\begin{array}{c}\text { Knee to Elbow Plank }-1 \mathrm{x} \\
20 \mathrm{sec} \text { (each leg) }\end{array}$ & $\begin{array}{c}\text { MB Clock, } 9: 00 \text { to } 3: 00 \text {, } \\
\text { 3:00 to } 9: 00-1 \text { x } 1 \text { (each } \\
\text { leg) }\end{array}$ \\
\hline $\begin{array}{c}\text { Straight Leg Med Ball Sit- } \\
\text { up }-1 \times 20\end{array}$ & $\begin{array}{c}\text { Straight Leg Med Ball Sit- } \\
\text { up }-1 \times 15\end{array}$ & $\begin{array}{c}\text { Straight Arm Rotations }-1 \\
\text { x } 8\end{array}$ \\
\hline $\begin{array}{l}\text { Seated Med Ball Circle }-1 \\
\text { x } 5 \text { (each way) }\end{array}$ & $\begin{array}{l}\text { Med Ball One-arm Push-up } \\
-1 \text { x } 4 \text { (each arm) }\end{array}$ & $\begin{array}{c}\text { Single Leg Scale }-1 \text { x } 3 \\
\text { (each leg) }\end{array}$ \\
\hline $\begin{array}{c}\text { Single Leg Scale }-1 \text { x } 3 \\
\text { (each leg) }\end{array}$ & $\begin{array}{l}\text { Seated twist with Med Ball } \\
\quad-1 \times 45 \mathrm{sec}\end{array}$ & $\begin{array}{c}\text { Seated Med Ball Circle }-1 \\
\text { x } 5 \text { (each way) }\end{array}$ \\
\hline $\begin{array}{c}\text { MB Clock, } 9: 00 \text { to } 3: 00, \\
\text { 3:00 to } 9: 00-1 \times 1 \text { (each } \\
\text { leg) }\end{array}$ & & $\begin{array}{c}\text { Knee to Elbow Plank - } 1 \text { x } \\
20 \text { sec (each leg) }\end{array}$ \\
\hline
\end{tabular}


Medicine Ball Training Protocol: Weeks $3 \& 4$ :

\begin{tabular}{|c|c|c|}
\hline Weekly Session 1 & Weekly Session 2 & Weekly Session 3 \\
\hline $\begin{array}{l}\text { Around the World }-1 \times 10 \\
\text { (each way) }\end{array}$ & $\begin{array}{c}\text { Haybales }-1 \times 15 \text { (each } \\
\text { way) }\end{array}$ & $\begin{array}{c}\text { Haybales }-1 \times 10 \text { (each } \\
\text { way) }\end{array}$ \\
\hline $\begin{array}{c}\text { Haybales }-1 \times 15 \text { (each } \\
\text { way) }\end{array}$ & $\begin{array}{l}\text { Seated twist w/ Med Ball - } \\
1 \times 30 \mathrm{sec}\end{array}$ & Woodchops -1 x 10 \\
\hline Woodchops - 1 x 10 & Med Ball Plank -1 x $60 \mathrm{sec}$ & $\begin{array}{l}\text { Partner Bent Arm Rotations } \\
-1 \times 10 \text { (each way) }\end{array}$ \\
\hline $\begin{array}{c}\text { Straight Arm Rotations }-1 \\
\text { x } 10\end{array}$ & $\begin{array}{l}\text { V-ups with Med Ball }-1 \mathrm{x} \\
8\end{array}$ & $\begin{array}{l}\text { Straight Leg Med Ball Sit- } \\
\text { up }-1 \text { × } 20\end{array}$ \\
\hline $\begin{array}{l}\text { Lunge with Twist }-1 \times 12 \\
\text { (each leg) } \\
* \text { twist to side of front leg* }\end{array}$ & $\begin{array}{c}\text { Russian Hamstring }-1 \times 25 \\
\text { (each leg) }\end{array}$ & Med Ball Plank -1 x $60 \mathrm{sec}$ \\
\hline $\begin{array}{c}\text { Bent Arm Rotations }-1 \mathrm{x} \\
10 \text { (each way) }\end{array}$ & $\begin{array}{c}\text { Knee to Elbow Plank }-1 \mathrm{x} \\
30 \mathrm{sec} \text { (each leg) }\end{array}$ & $\begin{array}{c}\text { MB Clock, } 9: 00 \text { to } 3: 00, \\
\text { 3:00 to } 9: 00-2 \times 1 \text { (each } \\
\text { leg) }\end{array}$ \\
\hline $\begin{array}{l}\text { Straight Leg Med Ball Sit- } \\
\text { up }-1 \times 20\end{array}$ & $\begin{array}{l}\text { Straight Leg Med Ball Sit- } \\
\text { up }-1 \times 20\end{array}$ & $\begin{array}{c}\text { Straight Arm Rotations }-1 \\
\times 8\end{array}$ \\
\hline $\begin{array}{l}\text { Seated Med Ball Circle }-1 \\
\text { x } 5 \text { (each way) }\end{array}$ & $\begin{array}{l}\text { Med Ball One-arm Push-up } \\
\quad-1 \text { x } 6 \text { (each arm) }\end{array}$ & $\begin{array}{l}\text { Single Leg Scale }-1 \text { x } 3 \\
\text { (each leg) }\end{array}$ \\
\hline $\begin{array}{l}\text { Single Leg Scale }-2 \times 3 \\
\text { (each leg) }\end{array}$ & $\begin{array}{l}\text { Seated twist with Med Ball } \\
-1 \times 60 \mathrm{sec}\end{array}$ & $\begin{array}{c}\text { Seated Med Ball Circle }-1 \\
\text { x } 5 \text { (each way) }\end{array}$ \\
\hline $\begin{array}{c}\text { MB Clock, } 9: 00 \text { to } 3: 00 \text {, } \\
\text { 3:00 to 9:00-2 x } 1 \text { (each } \\
\text { leg) }\end{array}$ & Med Ball Slams -1 × 8 & $\begin{array}{c}\text { Knee to Elbow Plank - } 1 \mathrm{x} \\
20 \mathrm{sec} \text { (each leg) }\end{array}$ \\
\hline $\begin{array}{l}\text { OH Squat with Calf Raise - } \\
\qquad 1 \times 15\end{array}$ & Med Ball Toss -1 x 8 & Figure $8-1$ x 60 seconds \\
\hline Figure $8-1 \times 60$ seconds & $\begin{array}{l}\text { OH Squat with Calf Raise - } \\
1 \times 15\end{array}$ & $\begin{array}{c}\text { Lunge with Twist }-1 \times 12 \\
\text { (each leg) }\end{array}$ \\
\hline
\end{tabular}




\begin{tabular}{|c|l|c|}
\hline & & $*$ twist to side of front leg* \\
\hline $\begin{array}{c}\text { Laying Med Ball } \\
\text { Woodchops }-1 \times 60 \\
\text { seconds }\end{array}$ & & $\begin{array}{c}\text { Hold OH half-squat } 1-45 \\
\text { second hold }\end{array}$ \\
\hline
\end{tabular}


Medicine Ball Training Protocol: Weeks 5 \& 6:

\begin{tabular}{|c|c|c|}
\hline Weekly Session 1 & Weekly Session 2 & Weekly Session 3 \\
\hline $\begin{array}{l}\text { Around the World }-1 \times 10 \\
\text { (each way) }\end{array}$ & $\begin{array}{c}\text { Haybales }-1 \times 15 \text { (each } \\
\text { way) }\end{array}$ & $\begin{array}{l}\text { Around the World }-1 \times 10 \\
\text { (each way) }\end{array}$ \\
\hline $\begin{array}{c}\text { Haybales }-1 \times 15 \text { (each } \\
\text { way) }\end{array}$ & $\begin{array}{c}\text { Seated twist w/ Med Ball - } \\
1 \times 30 \mathrm{sec}\end{array}$ & Woodchops -1 x 12 \\
\hline Woodchops - 1 x 10 & Med Ball Plank -1 x $60 \mathrm{sec}$ & $\begin{array}{l}\text { Partner Bent Arm Rotations } \\
-1 \times 10 \text { (each way) }\end{array}$ \\
\hline $\begin{array}{l}\text { Lunge with Twist }-1 \times 12 \\
\text { (each leg) } \\
\text { *twist to side of front leg, } \\
\text { ext. arms \& arms bent* }\end{array}$ & $\begin{array}{l}\text { V-ups with Med Ball }-1 \mathrm{x} \\
8\end{array}$ & $\begin{array}{l}\text { Seated twist w/ Med Ball - } \\
1 \times 45 \mathrm{sec} \text { (legs lifted) }\end{array}$ \\
\hline $\begin{array}{c}30 \text { sec Rest, repeat above } \\
* \text { no rest between } \\
\text { exercises } *\end{array}$ & $\begin{array}{c}\text { Russian Hamstring }-1 \times 25 \\
\text { (each leg) }\end{array}$ & Med Ball Plank -1 x $60 \mathrm{sec}$ \\
\hline $\begin{array}{l}\text { Straight Leg Med Ball Sit- } \\
\text { up }-1 \times 20\end{array}$ & $\begin{array}{c}30 \text { sec Rest, repeat above } \\
* \text { no rest between } \\
\text { exercises } *\end{array}$ & $\begin{array}{c}30 \text { sec Rest, repeat above } \\
\text { *no rest between }^{\text {exercises }}\end{array}$ \\
\hline $\begin{array}{c}\text { Seated Med Ball Circle }-1 \\
\text { x } 8 \text { (each way) }\end{array}$ & $\begin{array}{c}\text { Knee to Elbow Plank }-1 \mathrm{x} \\
30 \mathrm{sec} \text { (each leg) }\end{array}$ & $\begin{array}{c}\text { MB Clock, } 9: 00 \text { to } 3: 00 \text {, } \\
\text { 3:00 to 9:00-1 x } 2 \text { (each } \\
\text { leg) }\end{array}$ \\
\hline $\begin{array}{l}\text { Single Leg Scale with Med } \\
\text { Ball }-1 \times 3 \text { (each leg) }\end{array}$ & $\begin{array}{l}\text { Walking Lunge with raise, } \\
\text { opposite knee lift w/ heel } \\
\text { raise }-1 \times 12 \text { (each leg) }\end{array}$ & $\begin{array}{c}\text { Lunge with Twist }-1 \text { x } 12 \\
\text { (each leg) } \\
\text { *twist to side of front leg, } \\
\text { ext. arms \& arms bent* }\end{array}$ \\
\hline $\begin{array}{c}30 \text { sec Rest, repeat above } \\
\text { *no rest between }^{\text {exercises* }}\end{array}$ & $\begin{array}{l}\text { Med Ball One-arm Push-up } \\
-1 \text { x } 12 \text { switching arms }\end{array}$ & Figure $8-1 \times 60$ seconds \\
\hline $\begin{array}{c}\text { MB Clock, } 9: 00 \text { to } 3: 00 \text {, } \\
\text { 3:00 to 9:00 - } 1 \text { x } 2 \text { (each } \\
\text { leg) }\end{array}$ & Rock N Roll Up - 1 x 6 & $\begin{array}{c}30 \text { sec Rest, repeat above } \\
\text { *no rest between } \\
\text { exercises }\end{array}$ \\
\hline
\end{tabular}




\begin{tabular}{|c|c|c|}
\hline $\begin{array}{l}\text { OH Squat with Calf Raise - } \\
\qquad 1 \times 15\end{array}$ & $\begin{array}{c}30 \text { sec } \text { Rest, repeat above } \\
\text { *no rest between } \\
\text { exercises } *\end{array}$ & $\begin{array}{l}\text { Single Leg Scale with Med } \\
\text { Ball }-1 \times 3 \text { (each leg) }\end{array}$ \\
\hline Figure $8-1 \times 60$ seconds & Med Ball Slams -1 x 8 & $\begin{array}{l}\text { Knee to Elbow Plank }-1 \mathrm{x} \\
20 \mathrm{sec} \text { (each leg) }\end{array}$ \\
\hline $\begin{array}{l}\text { Laying Med Ball } \\
\text { Woodchops - } 1 \text { x } 60 \\
\text { seconds }\end{array}$ & Med Ball Toss -1 x 8 & $\begin{array}{l}\text { Hold OH half-squat } 1-45 \\
\text { second hold }\end{array}$ \\
\hline \multirow[t]{2}{*}{$\begin{array}{c}30 \text { sec } \text { Rest, repeat above } \\
\text { *no rest between } \\
\text { exercises* }\end{array}$} & $\begin{array}{l}\text { OH Squat w/ shoulder press } \\
\text { with Calf Raise }-1 \text { × } 15\end{array}$ & Weighted Superman $-1 \times 8$ \\
\hline & $\begin{array}{c}30 \text { sec } \text { Rest, repeat above } \\
\text { *no rest between } \\
\text { exercises* }\end{array}$ & $\begin{array}{c}30 \text { sec Rest, repeat above } \\
\text { *no rest between } \\
\text { exercises* }\end{array}$ \\
\hline
\end{tabular}

